\title{
Assessing the Nutritional Status of Hemodialysis Patients in Sub-Saharan Africa: Experience of Two Hemodialysis Centers in Niger
}

\author{
Hassan Diongole Moussa ${ }^{1^{*}}$, Zeinabou Maiga Moussa Tondi², Yaya Kane ${ }^{3}$, \\ Mahamane Aminou Mahamane Sani' ${ }^{2}$, Ide Abdou ${ }^{2}$, Illiassou Touré4, Aichatou Illa², \\ Adehossi Eric Omar ${ }^{1}$ \\ ${ }^{1}$ Nephrology Department of Zender University, Zender, Niger \\ ${ }^{2}$ Nephrology Department and Internal Medecine of Abdou Moumouni University, Niamey, Niger \\ ${ }^{3}$ Nephrology Department of Assane Seck University, Ziguinchor, Senegal \\ ${ }^{4}$ Hospital Center of Cahors \\ Email: *diongolen@yahoo.fr
}

How to cite this paper: Moussa, H.D., Tondi, Z.M.M., Kane, Y., Sani, M.A.M., Abdou, I., Touré, I., Illa, A. and Omar, A.E. (2016) Assessing the Nutritional Status of Hemodialysis Patients in Sub-Saharan Africa: Experience of Two Hemodialysis Centers in Niger. Open Journal of Nephrology, 6, 161-166.

http://dx.doi.org/10.4236/ojneph.2016.64021

Received: November 26, 2016

Accepted: December 25, 2016

Published: December 28, 2016

Copyright $\odot 2016$ by authors and Scientific Research Publishing Inc. This work is licensed under the Creative Commons Attribution International License (CC BY 4.0).

http://creativecommons.org/licenses/by/4.0/

(c) (†) Open Access

\begin{abstract}
Introduction: Patients with end-stage chronic renal failure (ESKD) have a significant impairment in their nutritional status. Our study is aiming at evaluating the nutritional status based on clinical and biological parameters. Patient and method: This is a prospective, cross-sectional, descriptive and analytical study carried out in two departments of nephrology/dialysis in Niger from 1 December 2014 to 31 March 2015. The assessment of nutritional status relied on the Body Mass Index (BMI), albuminemia, serum phosphate, hemoglobin, CRP, urea, creatinine levels. Results: Sixty-five patients were involved in the study. The mean age was $44.35 \pm 13$ years with a sex ratio of 2.09 in favor of men and an average dialysis duration of $43.47 \pm$ 36.55 months. The mean BMI was $21.60 \pm 4.47 \mathrm{~kg} / \mathrm{m}^{2}$. Undernutrition was noted in 19 patients (29.23\%), hypoalbuminemia was found in 13 patients, C-reactive protein (CRP) level was high in 11 patients. In comparative analysis according to the BMI, several parameters were significantly related to undernutrition: hypo-albuminemia, hyperphosphatemia, high CRP, hyperazotemia, anorexia, MUAC, comorbidities, central venous catheter. Conclusion: The prognostic value of undernutrition in chronic hemodialysis patients fosters early recognition and management of all nutritional disturbances in these patients. Assessment and monitoring of nutritional status in chronic hemodialysis require the simultaneous determination of several markers in order to weight the limits of each of the criteria taken in isolation.
\end{abstract}




\section{Keywords}

Nutrition, Hemodialysis, Niger

\section{Introduction}

Patients with chronic end-stage renal disease often show signs of protein-energy malnutrition in relation to an imbalance between inadequate nutritional intakes, catabolism and increased needs. Many causes contribute to its development, first of all anorexia and various comorbidities that are added to the various dietary restrictions laid down.

Despite regular dialysis, nutritional imbalances are often reported due to inflammation, infections, metabolic acidosis, as well as gastroparesis in diabetic patients [1], and oxidative stress related to uremia, but also to the technique of dialysis. These factors can lead to additional complications, sources of morbidity and mortality in dialysis.

Protein-energy malnutrition has been reported in $20 \%$ to $50 \%$ of patients treated with hemodialysis in several studies. Since early 1980s, malnutrition has emerged as a determinant of survival in this population. Its frequency varies according to the method of evaluation. In West Africa, very few studies have been published on this subject. In Senegal, a cross-sectional study of 142 cases in three hemodialysis centers in Dakar showed a prevalence of undernutrition of $43.2 \%$ [2].

In Niger no previous studies have been done so far. So our purpose in this multicenter study was to find out the nutritional status of the Nigerian dialysis population.

\section{Materials and Methods}

This was a prospective, cross-sectional, descriptive and analytical study carried out during the period 1 December 2014 to 31 March 2015 in the nephrology/dialysis departments of the national hospitals of Zinder and Lamordé.

We included in this study all chronic hemodialysis patients for at least three months, who gave informed consent.

Clinical and paraclinic sociodemographic data were collected from an individual survey form.

Patients were classified according to the WHO classification for nutritional status and were considered to be undernourished, with a BMI of all patients less than 18.5 $\mathrm{Kg} / \mathrm{m}^{2}$. The BMI can be used to assess a person's fat and determine their body size. The result of the BMI remains valid only for 18 to 65 -year-old.

The data were entered, monitored and analyzed using the EPI Info version 3.5.1 software. First, a descriptive analysis of the quantitative data was carried out, the results were presented as mean, $\pm \mathrm{SD}$ (standard deviation), and quantitative data in the form of percentages. Secondly, in order to determine the predictive factors of undernutrition, we divided the patients into 2 groups: group 1 (the undernourished) and group 2 (the not undernourished). The two groups were compared using the student and chi-square 
tests and Fisher's exact test. The differences were considered significant at $\mathrm{p}<0.05)$.

\section{Results}

We collated data concerning 65 patients, 44 men and 21 women, with a male/female ratio of 2.09. The mean age of the patients was $44.35 \pm 13.00$ years, with a median age of 44 years and extremes of 19 years and 73 years. The average age of women was $45.52 \pm$ 14.36 years with extremes from 19 years to 73 years. In men, the age varied from 20 years to 72 years with an average of $43.79 \pm 12.43$ years.

In our series, $47.69 \%$ had a liberal function, we noted a history of hypertension and diabetes in $90.8 \%$ and $4.6 \%$ respectively. Initial nephropathy was dominated by nephroangiosclerosis in $62 \%$, and was not determined in $26 \%$ of cases. The mean duration of dialysis was $43.47 \pm 36.55$ months. Most of the patients had arteriovenous fistula (FAV) placed, only $4.62 \%$ received a central venous catheter (CVC). The mid-upper arm circumference (MUAC) of the patients in our series was $26.50 \pm 4.09 \mathrm{~cm}$ and the extremes were $20 \mathrm{~cm}$ and $37 \mathrm{~cm}$.

Eighteen patients $(27.7 \%)$ had anorexia, the mean albumin levels were $42.28 \pm 5.73$ $\mathrm{g} / \mathrm{l}$ with extremes of $51.90 \mathrm{~g} / \mathrm{l}$ and $26.40 \mathrm{~g} / \mathrm{l}$. Mean phosphoric acid was $3.91 \pm 1.50 \mathrm{mg} /$ dl. The average CRP of our patients was $9.79 \pm 13.44 \mathrm{mg} / \mathrm{l}$ and the mean hemoglobin level of the patients was $8 \mathrm{~g} / \mathrm{dl}$. The average urea rate of our patients was $0.89 \pm 0.35 \mathrm{~g} / \mathrm{l}$ and the mean serum creatinine level was $106.32 \pm 44.219 \mathrm{~g} / \mathrm{dl}$.

In our series, we carried out a comparative study, and the BMI was considered as a common criterion to distribute the study population in 2 groups.

The prevalence of undernutrition was $29.30 \%$, i.e. 19 patients in the undernutrition group. We tried to find out the link between undernutrition and certain clinical parameters. There is a statistically significant relationship between undernutrition and anorexia $(\mathrm{p}=0.0001)$, MUAC $(\mathrm{p}=0.0003)$, vascular access $(\mathrm{p}=0.03)$ and comorbidities $(\mathrm{p}$ $=0.04)$. There is no connection with age and duration of dialysis.

Biologically, the levels of albumin $(p=0.03)$, phosphorus $(p=0.03)$, CRP $(p=0.04)$ and urea $(\mathrm{p}=0.001)$ were also associated with undernutrition. On the other hand, we did not observe any significant relationship between undernutrition and parameters such as hemoglobin and serum creatinine.

\section{Discussion}

The general objective of this work was to contribute to evaluating the nutritional status of chronic hemodialysis in Niger. The specific objectives should enable us to specify the prevalence of undernutrition in this population and to determine the predictive factors of undernutrition in chronic hemodialysis. In our series, the overall average age was $44.35 \pm 13$ years with extremes of 19 years and 73 years. Our result is closer to those of Camara et al. [3] and Es-sebbani [4] who obtained respectively $45.64 \pm 17$ years and 48, $43 \pm 17.7$ years.

In our series, the sex ratio was substantially equal to 2, close to the result of Camara et al. [3] who found a sex ratio of 1.8 . 
High blood pressure (hypertension) was present in $90.8 \%$ of our patients. Our result was more important than that of Es-sebbani [4] who got $22 \%$. This high proportion of hypertensive patients can be explained by the fact that high blood pressure is a major cause of chronic renal insufficiency (CRI). Moreover, hypertension might result from CKD: patients admitted in nephrology/dialysis departments are most often at the end stage. During CKD, there is early onset form of high blood pressure, often preceding renal failure, especially during glomerular, vascular nephropathies and polycystic kidney disease [5].

The mean duration of hemodialysis in our series was $43.47 \pm 36.55$ months. Es-sebbani [4] and Ondele in Senegal [2] came out with an average duration of hemodialysis of $76.12 \pm 43$ months and $86.57 \pm 31.10$ months, respectively. This difference is probably due to the time spent in providing care within these facilities.

BMI is the main evaluated parameter in all patients. The BMI averaged 21.60 \pm 4.47 $\mathrm{kg} / \mathrm{m}^{2}$. Thus, El Ati [6] had an average BMI of $22.17 \pm 0.6 \mathrm{~kg} / \mathrm{m}^{2}$, however a lower prevalence than ours (16\%) with a BMI lower than $18.5 \mathrm{~kg} / \mathrm{m}^{2}$.

The mid-upper arm circumference (MUAC) in our series was $26.50 \pm 4.09 \mathrm{~cm}$. Camara et al. [3], obtained an MUAC of $22.62 \pm 3 \mathrm{~cm}$. Anorexia was present in $27.69 \%$ of hemodialysis patients. Ondele et al. [2] got $24.8 \%$. This could be explained by several factors: the restricted diet in liquid, sodium, phosphorus, potassium, and especially, inadequate dialysis dose.

The mean albumin level was $42.28 \pm 5.73 \mathrm{~g} / \mathrm{l}$. Es-sebbani [4] and Ondele [2] came out with $40 \pm 6.57 \mathrm{~g} / \mathrm{l}$ and $41.70 \pm 4.82 \mathrm{~g} / \mathrm{l}$ respectively. The mean phosphorus level was 3.91 $\pm 1.50 \mathrm{mg} / \mathrm{dl}$. Es-sebbani [4] found $4.4 \pm 1.4 \mathrm{mg} / \mathrm{dl}$. The average CRP of the patients was $9.79 \pm 13.44 \mathrm{mg} / \mathrm{l}$. Es-sebbani [4] obtained an average CRP of $13.13 \pm 13 \mathrm{mg} / \mathrm{l}$. In several series, CRP remains high in hemodialysis patients. Different factors contribute to the establishment of a chronic inflammatory state in the patient with CKD [6]: They can be secondary to the kidney disease itself, particularly oxidative stress due to the decrease in antioxidant defenses secondary to CKD, and the accumulation of molecules of the advanced glycation end-products (AGE) type. The inflammatory phenomena induced by hemodialysis treatment may be linked to the interaction between the blood and the dialysis membrane or to the quality of water used for performing dialysis. Infectious problems are common in hemodialysis, as are complications of the vascular access, joint problems, all of which can induce microinflammatory states. Therefore, the causes of chronic inflammation are multiple, entangled, but not necessarily accessible to a univocal treatment in chronic kidney disease. Chronic inflammation has a major nutritional impact: it is associated with anorexia and a decrease in protein synthesis. It is also a catabolic factor, in particular by the ubiquitin-proteasome pathway [7].

The mean hemoglobin in our study was $8.39 \pm 1.68 \mathrm{~g} / \mathrm{dl}$. Es-sebbani [4] found a rate substantially equal to $10 \mathrm{~g} / \mathrm{l}$. This is consistent with the fact that not all patients receive treatment with erythropoietin.

The prevalence of undernutrition in our series was $29.23 \%$ for a BMI lower than 18.5 $\mathrm{kg} / \mathrm{m}^{2}$. Our results are more significant than those of Hassoum in Morocco [8] and El 
Ati [6] who found a prevalence of $26 \%$ and $14.21 \%$ respectively for a BMI lower than $18.5 \mathrm{~kg} / \mathrm{m}^{2}$.

Old age and duration of dialysis were found to be correlated with undernutrition in several studies [9], but were not significant in our series. On the other hand, vascular access procedure using a central venous catheter was correlated with undernutrition ( $p$ $=0.03$ ). This result is consistent with the literature [7]. In our series, comorbidities were also correlated with undernutrition. Our results were identical to the findings by Es-sebbani in Morocco [4]. Anorexia and MUAC were also correlated with undernutrition. Ondele [2] also found a relation between undernutrition and anorexia. Anorexia in CKD is attributed to many factors [10], such as frequent hospitalizations, multiple drug treatments, comorbidities, depression, poverty and uremic toxins.

In our series, hypo-albuminemia, hyperphosphatemia, hyperazolemia and a high rate of CRP were positively correlated with undernutrition. This result is identical to the results of Es-sebbani [4] who found a correlation between hypo-albuminemia and undernutrition. For Ondele [2], hypo-albuminemia and a high CRP level correlated with undernutrition. This result corresponds to the data in the literature: albumin is an indicator of visceral proteins. Its normal plasma concentrations are about $42 \pm 3 \mathrm{~g} / \mathrm{l}$, and remain high $38 \mathrm{~g} / \mathrm{l}$ even in the very old subjects. Given prolonged half-lives ( 22 days), decreased plasma albumin concentrations (less than $35 \mathrm{~g} / \mathrm{l}$ ) indicate prolonged severe malnutrition [11]. Malnutrition is the leading cause of hypo-albuminemia in CKD. The level of albumin may be low in apparently well-fed hemodialysis patients, and then gradually decreases according to the degree of malnutrition [12].

Hyperphosphatemia and hyperazolemia were also correlated with undernutrition in our series. Our result could probably be explained by inadequate and not enough dialysis (Sessions were less than 12 hours on a weekly basis).

\section{Conclusion}

The purpose of our preliminary study was to evaluate the nutritional status and predictive factors of malnutrition in chronic hemodialysis in Niger. Thus, at the end of the study, it appears that protein-energy malnutrition remains frequent in our hemodialysis patients, and its prevalence was $29.23 \%$. Hypoalbuminemia, hyperphosphatemia, hyperazolemia, high CRP, anorexia and MUAC below normal were correlated with this type of undernutrition.

\section{References}

[1] Kuhlmann, M.K., Kribben, A., Wittwer, M., et al. (2007) OPTA-Malnutrition in Chronic Renal Failure. Nephrology Dialysis Transplantation, 22, iii 13-iii 19.

[2] Ondelle, A.-P., Ka, E.H.F., Seck, S.M., Cissé, M., Niang, A. and Diouf, B. L'évaluation de l'état nutritionnel des hémodialysés de Dakar. http://www.sciencedirect.com/science/article/pii/s1769725514001679

[3] Camara, M., Kaba, M.L., Camara, M.O., Baldé, N.M. and Bah, A.O. (2014) Touré: L’évaluation nutritionnel des hémodialysés au centre national d'hémodialyse de Donka.

[4] Es-sebbani, M. (2011) Evaluation de l'état nutritionnel chez les hémodialysés chroniques. 
Thèse Maroc.

[5] Girard, S., Bruckert, E. and Turpin, G. (1998) Prevention des maladies artérielles périphériques par le traitement des dyslipidemirs. Angiologie, 50, 57-64.

[6] El Ati, Z., Sioud, O., Sbaa, M. and Bouzidi, H. (2014) Malnutrition chez l'insuffisante rénale chronique au stade d'hémodialyse.

http://www.sciencedirect.com/science/article/pii/S1769725514001783

[7] Combe, C., Cazin, M.C., Vendrly, B., Bocquentin, F. and Chauveau, P. (2003) Les marqueurs inflammatoire chez les dialysés: Données épidemiologiques. Néphrologie, 7, 343-346.

[8] Hakimoun, H. (2008) Facteurs de risque de dénutrition chez les dialysés. Thèse Maroc.

[9] Krasnicka, M., Sulowicz, W. and Kopec, J. (2005) Factors Predisposing to Malnutrition Development in the Patients on Maintenance Hemodialysis. Przegl Lek, 62, 274-278.

[10] Heng, A.E. and Cano, N.J.M. (2010) Nutritional Problems in Adult Patients with Stage 5 Chronic Kidney Disease on Dialysis (Both Haemodialysis and Peritoneal Dialysis). NDT Plus, 3, 109-117.

[11] Couet, C. (2001) Exploration de l'état nutritionnel. In: Traité de nutrition clinique de Padulte, Flammarion, Paris, France.

[12] Stenvinkel, P., et al. (2000) Are There Two Types of Malnutrition in Chronic Renal Failure? Evidence for Relationships between Malnutrition, Inflammation and Atherosclerosis (Mia Syndrome). Nephrology Dialysis Transplantation, 15, 953-960.

Submit or recommend next manuscript to SCIRP and we will provide best service for you:

Accepting pre-submission inquiries through Email, Facebook, LinkedIn, Twitter, etc.

A wide selection of journals (inclusive of 9 subjects, more than 200 journals)

Providing 24-hour high-quality service

User-friendly online submission system

Fair and swift peer-review system

Efficient typesetting and proofreading procedure

Display of the result of downloads and visits, as well as the number of cited articles

Maximum dissemination of your research work

Submit your manuscript at: http://papersubmission.scirp.org/

Or contact ojneph@scirp.org 